\title{
Socioeconomic State of Sample Layer Farmers in Bangladesh: An Investigation Based on Dhaka and Kishorganje Districts
}

\author{
Md. Mahmudul Hassan ${ }^{1}$ \\ Bangladesh University of Business and Technology (BUBT)
}

The objective of the study was to establish how farm inputs influence poultry layer production in Bangladesh from a sample of 100 poultry farmers selected from Savar and Dhamrai Upazilla under Dhaka and Bajitpur and Kuliarchar Upazilla under Kishorganje district. The study was also carried out to understand the socio-economic characteristics of layer farmers categorizing them as small, medium and large farms. Data were analyzed with both descriptive and inferential statistics. The results show that all the production variables analyzed were positive and statistically significant. Results showed that among different input factors, doc size and feed input played crucial role in egg output.

Keywords: egg production, poultry farmers, Bangladesh, agriculture, socioeconomy

\section{INTRODUCTION}

One of the vital challenge of Bangladesh agriculture is its capability to nourish the ever-increasing population with satisfactory food value i.e. calorie and protein. Poultry industry is one of the chief among livestock sub-sector that is devoted to supply cheap sources of good quality nutritious animal protein (Shamsuddoha, 2010). Poultry farming is a sub-sector of the Agriculture sector in Bangladesh. By far poultry is the leading livestock group containing generally of chickens, ducks and turkeys (FAO 2009). In total, poultry products (egg and meat) constitute $30 \%$ of all animal protein consumed worldwide (Permin A. et. al. 2005). That is poultry meat accounts for $30 \%$ of global meat consumption. In global meat production poultry meat is taking the second place after pork (FAO Corporate Document Repository, 2007).

The poultry is a crucial avenue in nurturing agricultural growth. Bangladesh poultry plays an important economic role for $73 \%$ of rural people who lives in rural areas (Reneta 2005). In 2020, per capita poultry meat consumption is anticipated to extent $8.42 \mathrm{Kg}$, which is now nearly $4 \mathrm{~kg}$, while in Pakistan $5.5 \mathrm{~kg}$ and in the U.S. over 50kg. as per as the World's Poultry Science Association Bangladesh Branch (Dhaka tribune, 2016).In the nineties total investment in the poultry sector was only Tk 15 hundred crore, but now it is more than Tk 15 thousand crore. This has created job opportunity for more than 60 lakh people (Ali et al. 2012)

The fisheries and livestock sectors are two chief pillars of our economy. Role of these two sectors to total GDP was 3.69 and 7.73 percent respectively (MoFL, 2016). They are also driving the country towards achieving the Sustainable Development Goals that focuses on 'achieve food security and improved nutrition'. Poultry industry has the prospective to support Bangladesh reach the UN Sustainable 
Development Goals (SDGs) of reducing malnutrition and ensuring better health for the countrymen. Among 17 SDGs, ending hunger, achieving food security and improving nutritional status are the ones that the poultry industry can deal with and pay much through providing protein items. (Dhaka Tribune, August 24, 2016)

According to Department of Livestock (DLS) about 6.5 percent of national GDP is covered by the livestock sector (Banglapedia). Annual growth rate of poultry is $15-18 \%$. Contribution in GDP is $2.4 \%$ (BPSCC). About $38 \%$ of animal protein originates from poultry meat and egg (Layer Rearing Manual, 2010, BLRI).

From the table below (table 1) we see that in FY 2016-17 the contribution of livestock sector in GDP at constant price was $1.60 \%$ and the rate of growth was $3.32 \%$. And this is a very positive sign that the growth rate of livestock contribution in national GDP is rising over the period of time. With the annual growth rate of $7.65 \%$ (according to BBS based on last nine months from July 2016-March 2018) the growth rate of livestock is also supposed to rise gradually.

TABLE 1

LIVESTOCK CONTRIBUTION IN GDP

\begin{tabular}{|c|c|c|c|c|c|c|c|c|}
\hline Indicators & $\begin{array}{c}\mathbf{2 0 0 9 -} \\
\mathbf{1 0}\end{array}$ & $\mathbf{2 0 1 0 - 1 1}$ & $\begin{array}{c}\mathbf{2 0 1 1 -} \\
\mathbf{1 2}\end{array}$ & $\begin{array}{c}\mathbf{2 0 1 2 -} \\
\mathbf{1 3}\end{array}$ & $\begin{array}{c}\mathbf{2 0 1 3 -} \\
\mathbf{1 4}\end{array}$ & $\begin{array}{c}\mathbf{2 0 1 4 -} \\
\mathbf{1 5}\end{array}$ & $\begin{array}{c}\mathbf{2 0 1 5 -} \\
\mathbf{2 0 1 6}\end{array}$ & $\begin{array}{c}\mathbf{2 0 1 6 -} \\
\mathbf{2 0 1 7}\end{array}$ \\
\hline $\begin{array}{c}\text { GDP(Base:2005- } \\
\text { 06)** }\end{array}$ & 2.06 & 1.98 & 1.9 & 1.84 & 1.78 & 1.73 & 1.66 & 1.60 \\
\hline $\begin{array}{c}\text { Growth rate of } \\
\text { GDP }\end{array}$ & 2.51 & 2.59 & 2.68 & 2.74 & 2.83 & 3.1 & 3.21 & 3.32 \\
\hline
\end{tabular}

**GDP calculated at constant price (Source: BBS); p denotes provisional; Prepared by Dr. Hossan Md. Salim, LE Section,DLS.

Source: DLS, 2017, Livestock Economy at a Glance 2016-17

Though the share of the animal farming in GDP is small, it keeps huge contribution towards meeting the requirements of daily essential animal protein.

The contribution of livestock and poultry in the national economy of Bangladesh was presented in Table 2 below.

TABLE 2

CONTRIBUTION OF LIVESTOCK AND POULTRY IN THE NATIONAL ECONOMY OF BANGLADESH

\begin{tabular}{lc}
\hline Particulars & Contribution \\
\hline Contribution of Livestock in Gross Domestic Product (GDP), (2016-17)p & $1.60 \%$ \\
GDP growth rate of Livestock (2016-17) p & $3.32 \%$ \\
GDP volume (Current price) in Crores (Taka), (2016-17) p & 35,576 \\
Share of Livestock in Agricultural GDP (2016-17) p & $14.31 \%$ \\
Employment (Directly) & $20 \%$ \\
Employment (Partly) & $50 \%$ \\
Cultivation of land by livestock & $50 \%$ \\
Fuel supply from livestock and poultry & $25 \%$ \\
\hline
\end{tabular}

Source: DLS, 2017, Livestock Economy at a Glance 2016-17

It is also to be noted that livestock sector has been earning foreign currency by exporting meat and livestock products to USA, UAE, China, Kuwait, Canada, Japan and Maldives (Bangladesh Economic Review 2017, page 111) 
Even with the poultry sector is an important part of our national economy, currently there has been no study that investigates the status of poultry sector from the production function perspective. In order to establish a sustainable poultry friendly plan for the country, it is essential to estimate the production function. Given the fact that Bangladesh is faced with different challenges as far as the livestock subsector is concerned, it then becomes crucial to quantitatively measure the existing level and determinants of factors affecting poultry output.

However, an attempt has been made in order to tackle the issue. The specific objectives of this study were (i) to estimate the determinants of poultry layer farms output by estimating the elasticity of production of the inputs; and (ii) to analyze the socioeconomic characteristics of table poultry layer farms in Savar and Dhamrai Upazilla.

A good number of studies have been undertaken on different aspects of poultry and poultry farm in Bangladesh. The studies include production performance of poultry and demand for poultry (Talukder et al. 1982, Ukil 1994; Islam K.M. Nabiul 2001, Khan et. al. 2006, Rahman et al. 2009, Shah et al, 2011), measuring relative costs, returns and economic analyses (Miah 1990, Ahmed et al. 1995, Bhuiyan, 2003; Alam, 2004, Islam et al. 2016), benefit and profitability analysis of contract farming (Vukina and Foster, 1998, Begum I. A. et al 2000, Karim, 2000, Bairagi 2004 and Jabbar et. al. 2007), effectiveness of trained farmers (Ershad et al. 2004), marketing and value chain analysis (Rahman, 20004, USAID-ATDP 2005), role of NGO in poultry (Ahmed 2001, Shamsuddoha M. 2009), role of poultry in biogas and electricity generation (Zaman 2007, Sajib et. al. 2015, Alam 2017), environmental impact of the poultry sector in Bangladesh (Akter et al. 2004) etc. Hassan Md. M. (2018, 2019) studied the efficiency of poultry broiler and layer farm in Bangladesh using stochastic frontier analysis.

The present study differs from the previous study in Bangladesh by introducing the concept of wellknown production function and also analyzing the socioeconomic characteristics of poultry layer farmers which makes this paper unique for the Bangladesh context.

\section{DATA AND METHODOLOGY}

\section{Materials and Methods}

For the present study Savar and Dhamrai Upazilla under Dhaka district and Bajitpur and Kuliarchar Upazilla under Kishorganje district were selected. The data was collected through random selection of poultry farmers which gave the opportunity for fifty poultry farmers from each district making a total of 200 poultry farmers i.e. hundred farmers located in Dhaka and the rest hundred from Kisharganj. Data collection was done by means of structured questionnaire and were analyzed using Stochastic Production Frontier Model. Stata 14 was applied to run the frontier model.

\section{Source of Data}

Both primary and secondary data were used. The primary data was collected from farmers involved in the production of poultry egg. Beside this, the study also employed information from different issues of Bangladesh Statistical Year Book published by Bureau of Statistics (BBS), Economic Review published by Finance Ministry and "Farm Poultry and Livestock Survey 2007-08" by BBS. About 115 poultry farmers were selected and after necessary correction 100 poultry farmers were finalized for our research study

\section{The Empirical Model}

For this study, the production technology of poultry egg producers was assumed to be specified by the Cobb - Douglas frontier production function defined as follows:

$Y=a X_{1}^{\beta_{1}} X_{2}^{\beta_{2}} X_{3}^{\beta_{3}} X_{4}^{\beta_{4}} X_{5}^{\beta_{5}} X_{6}^{\beta_{6}} X_{7}^{\beta_{7}} e^{V_{1}-U_{1}}$

$Y=f\left(X_{a} ; B_{i}\right) e^{E}$ 
Where- $Y=$ Quantity of egg produced; $\mathrm{X}_{\mathrm{a}}=\mathrm{A}$ vector of input and other explanatory variable quantities; $\mathrm{Bi}=\mathrm{A}$ vector of unknown parameter to be estimated; $\mathrm{e}=$ Error term

Cobb-Douglas production function model can be estimated using OLS (ordinary least square) method, in a linear form. The estimated equation was:

$\ln Y_{i}=\ln a+\beta_{1} \ln X_{1 i}+\beta_{2} \ln X_{2 i}+\beta_{3} \ln X_{3 i}+\beta_{4} \ln X_{4 i}+\beta_{5} \ln X_{5 i}+\left(v_{i}-u_{i}\right)$

$\ln Y_{i}=\beta_{0}+\beta_{1} \ln X_{1 i}+\beta_{2} \ln X_{2 i}+\beta_{3} \ln X_{3 i}+\beta_{4} \ln X_{4 i}+\beta_{5} \ln X_{5 i}+\left(v_{i}-u_{i}\right)$

Where,

$\ln =$ the natural logarithm to base e

$\mathrm{Y}_{\mathrm{i}}=$ Output of the poultry farmer per batch (total egg produced per batch in $\mathrm{kg}$ ) $\mathrm{X}_{1}=$ Number of days worked in a year

$\mathrm{X}_{2}=$ Size of Doc (number of birds per batch)

$\mathrm{X}_{3}=$ Cost of feed per batch (in taka)

$\mathrm{X}_{4}=$ Value of capital (in taka)

$\mathrm{X}_{5}=$ Farm Area measured in decimal

$v_{i}=$ random error assumed to be independent of $\mathrm{u}_{\mathrm{i}}$, identical and normally distributed with zero mean and constant variance $\mathrm{N}\left(0, \partial^{2}\right)$

$U i=$ Technical efficiency effect which are the result of behavior factors that could be controlled by an efficient management.

In equation $3 \beta_{0}$ is the intercept; $U i$ denotes the specific technical efficiency factor for farm $i$; and $v i$ represents a random variable for farm $i$. The $\beta$ coefficients are unknown parameters to be estimated, by the method of maximum likelihood, using the econometric package Stata version 14.

\section{RESULT ANALYSIS AND DISCUSSION}

\section{Descriptive Statistics of Layer Farmers}

In the study area the mean flock size was 2467 birds. The average experience of farmers was 11 years. Farmers' average age was 42. The poultry farmer's average family members were 5.

TABLE 3

LAYER DESCRIPTIVE STATISTICS

\begin{tabular}{ccccrc}
\hline Variable & Obs & Mean & Std. Dev. & Min & Max \\
\hline Flock size & 100 & 2435.8 & 2497.306 & 70 & 8500 \\
Experience & 100 & 11.423 & 5.494681 & 1 & 24 \\
Age & 100 & 42.05 & 9.020039 & 23 & 63 \\
& 100 & 5.00 & 1.687745 & 0 & 8 \\
Family members & & & & & \\
\hline
\end{tabular}

Source: Field survey, 2015

\section{Cobb Douglas Function for Layer Farms}

The coefficient of labor input employed $\left(\ln \mathrm{X}_{1}\right)$ in man per days was positive as expected and significant at $1 \%$ significance level. The more attention farmers paid to the birds the higher the poultry output. Thus the 0.09 elasticity of labor suggest that a $1 \%$ increase in labor use would result to an increase of 0.09 percent in the farm output given that other inputs are constant. 
DOC size $\left(\ln \mathrm{X}_{2}\right)$ was significant at $1 \%$ level and positive in sign. This means that farmers who stock higher number of birds were producing more than those with smaller doc size. The coefficient of number of chicks is 0.26 implying that one percent increase in the number of day old chicks will result in a 0.26 percent in the number of egg produced per cycle given that other inputs are constant.

The estimated coefficient for feed input $\left(\ln \mathrm{X}_{3}\right)$ was positive and statistically significant at $1 \%$ significant level. Feed is a central resource used in poultry production. The appropriate amount of feed used at different stages in life of poultry bird determines the level of success and profitability in poultry business. Therefore, 0.30 elasticity of feed input suggest that a $1 \%$ increase in feed inputs, would result to an increase of 0.30 percent in the farm output.

The coefficient of capital input $\left(\ln \mathrm{X}_{4}\right)$ is positive and significant at $1 \%$ level. The amount of capital inputs per farm determines the level of investment in such farm. Therefore, 0.08 elasticity of capital suggests that a $1 \%$ increase in capital inputs would result to an increase of 0.08 percent in the farm output. The estimated coefficient for farm area $\left(\ln \mathrm{X}_{5}\right)$ measured in decimal was positive, which conform to a priori expectation and was significant at $5 \%$ level. Therefore, the 0.05 elasticity of farm size implies that a $1 \%$ increase in farm size, ceteris paribus, would lead to an increase of 0.05 percent in the output of poultry layer farmers holding other things unchanged.

TABLE 4

COBB-DOUGLAS PRODUCTION FUNCTION FOR SAMPLE LAYER FARMS

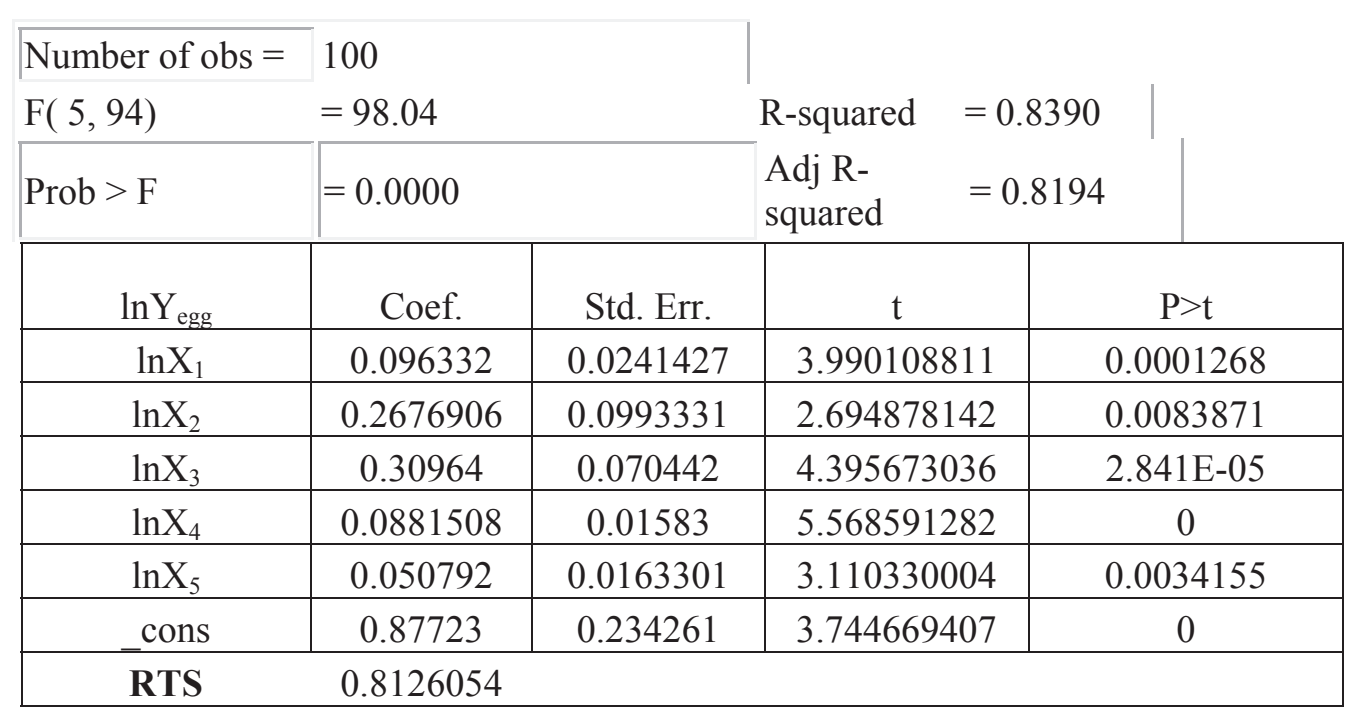

Source: Author's Calculation from the Field Data

Note: Where, $\ln \mathrm{X}_{1}=$ Labor input, $\ln \mathrm{X}_{2}=\mathrm{DOC}$ size, $\ln \mathrm{X}_{3}=$ Feed input, $\ln X_{4}=$ Capital input and $\ln X_{5}=$ Area of farm

\section{SOCIOECONOMIC CHARACTERISTICS OF LAYER FARMERS}

\section{Age Distribution of Layer Farm Owners}

The selected layer farm owners were grouped into six categories according to their ages. The average age of the selected farmers was observed to be 42 ranging from a minimum of 23 to a maximum of 63 years. The different age group of layer farm owners is presented in table 5. 
TABLE 5

DISTRIBUTION OF LAYER FARM OWNERS ACCORDING TO AGE

\begin{tabular}{cccc}
\hline Age group (years) & Freq. & Percent & Cum. \\
\hline $18-24$ & 1 & 1.00 & 1.00 \\
$25-31$ & 9 & 9.00 & 10.00 \\
$32-38$ & 26 & 26.00 & 36.00 \\
& 36 & 36.00 & 72.00 \\
$39-45$ & 15 & 15.00 & 87.00 \\
& 13 & 13.00 & 100.00 \\
$46-52$ & & & \\
Above 52 & & & \\
\hline Total & $\mathbf{1 0 0}$ & $\mathbf{1 0 0 . 0 0}$ & \\
\hline
\end{tabular}

Source: Field survey, 2015

It is clear from the table that of the 100 sample owners none of the layer farm owners belongs to the age below 18 years. The table also shows that the owners of these farms were relatively middle aged people. The highest part of the age group fell into the age group of 39 to 45 years which was 36 percent, while 26 percent of layer farm owners fell into the age group between 32 to 38 years.

\section{Education Level of Layer Farm Owners}

Table 6 shows that most of owners of the selected layer farms were educated. Greater percentage of respondents could read and write only. It can be seen from the table that $24 \%$ of the farmers could read and write only followed by $20 \%$ who had secondary education. While $19 \%$ had primary education, $8 \%$ had tertiary education. Besides, $8 \%$ had quranic education. And percentage of no formal or madrasha education was 21 percent. These 21 percent respondents in the study area had no education. It is true that to conduct the poultry production activities conventional education is not required except knowledge about poultry farming only.

TABLE 6 DISTRIBUTION OF RESPONDENTS ACCORDING TO LEVEL OF EDUCATION

\begin{tabular}{cccc}
\hline Other Occupation & Freq. & Percent & Cum. \\
\hline No Education & 21 & 21.00 & 21.00 \\
Primary Education & 19 & 19.00 & 40.00 \\
Quranic Education & 8 & 8.00 & 48.00 \\
& 24 & 24.00 & 72.00 \\
Read and Write only & 20 & 20.00 & 92.00 \\
& 8 & 8.00 & 100.00 \\
Secondary Education & & & \\
Tertiary Education and above & & & \\
\hline \hline Total & 100 & 100.00 & \\
\hline
\end{tabular}

Source: Field survey, 2015

\section{Experience of Layer Farm Owners}

In the study area majority of farmers had 11 to 15 years of experience. It is seen from the table below that $33 \%$ farmers had experience of 11 to 15 years. $20 \%$ had farming experience that ranged between 6 to 10 years. Only $16 \%$ had experience above 20 years. 
TABLE 7

DISTRIBUTION OF RESPONDENTS ACCORDING TO YEARS OF EXPERIENCE

\begin{tabular}{ccrr}
\hline Years of Experience & Freq. & Percent & Cum. \\
\hline$\leq 5$ & 8 & 8.00 & 8.00 \\
$6-10$ & 20 & 20.00 & 28.00 \\
$11-15$ & 33 & 33.00 & 61.00 \\
& 23 & 23.00 & 84.00 \\
$16-20$ & 16 & 16.00 & 100.00 \\
Above 20 & & & \\
\hline Total & 100 & 100.00 & \\
\hline
\end{tabular}

Source: Field survey, 2015

Farm Location of Layer Farm Owners

From our study we see that most of the poultry farms were located in rural area (73.80 percent) while 26.19 percent farms were located in urban area. That is most of the farms were located in rural area.

TABLE 8

DISTRIBUTION OF RESPONDENTS ACCORDING TO LOCATION OF FARM (AGGREGATE)

\begin{tabular}{cccc}
\hline Location of Farm & Freq. & Percent & Cum. \\
\hline Rural & 67 & 73.80 & 73.80 \\
Urban & 33 & 26.19 & 100.00 \\
\hline Total & $\mathbf{1 0 0}$ & $\mathbf{1 0 0 . 0 0}$ & \\
\hline
\end{tabular}

Source: Field survey, 2015

As can be seen from the table above (table 78$)$ that most of the poultry farms ( 73.80 percent) were located in rural area. Of them most of the farms belong to small farm category. Very few amount of farms located in rural area were large farm category.

TABLE 9

DISTRIBUTION OF RESPONDENTS ACCORDING TO LOCATION OF FARM (SMALL)

\begin{tabular}{cccr}
\hline Location of Farm & Freq. & Percent & Cum. \\
\hline Rural & 35 & 89.74 & 89.74 \\
Urban & 4 & 10.25 & 100.00 \\
\hline Total & $\mathbf{3 9}$ & $\mathbf{1 0 0 . 0 0}$ & \\
\hline
\end{tabular}

Source: Field survey, 2015

The table above shows that in 89.74 percent cases small poultry farms were located in rural area. Only 10.25 percent farms were in urban area. Well this is true that many poultry farms particularly small farms in Bangladesh are operating their activities in remote rural area. 


\section{TABLE 10}

DISTRIBUTION OF RESPONDENTS ACCORDING TO LOCATION OF FARM (MEDIUM)

\begin{tabular}{cccc}
\hline Location of Farm & Freq. & Percent & Cum. \\
\hline Rural & 23 & 67.34 & 67.34 \\
Urban & 11 & 32.35 & 100.00 \\
\hline Total & $\mathbf{3 4}$ & $\mathbf{1 0 0 . 0 0}$ & \\
\hline
\end{tabular}

Source: Field survey, 2015

Table above shows that in case of medium farm in 67.34 percent cases farm were located in rural area while in 32.25 percent cases farm were located in urban area. That is in aces of medium farms most of them belong to rural area. On the other hand, the following table shows the distribution of location of large farm in the sample area where we see that in 66.66 percent case farm were located in urban area while in 33.33 percent case only farm were located in rural area. This is an important reason of efficiency of large scale farm as because they are able to get good transport facility and available number of buyers located in the area and outside the area as well.

TABLE 11

DISTRIBUTION OF RESPONDENTS ACCORDING TO LOCATION OF FARM (LARGE)

\begin{tabular}{cccc}
\hline Location of Farm & Freq. & Percent & Cum. \\
\hline Rural & 9 & 33.33 & 33.33 \\
Urban & 18 & 66.66 & 100.00 \\
\hline Total & $\mathbf{2 7}$ & $\mathbf{1 0 0 . 0 0}$ & \\
\hline
\end{tabular}

Source: Field survey, 2015

\section{Gender Distribution of Layer Farm Owners}

From the study we see that in the sample area most of the poultry farmers were male which was 63 percent as can be seen from the table below. And the percentage of female was 37 .

TABLE 12

DISTRIBUTION OF RESPONDENTS ACCORDING TO GENDER (AGGREGATE)

\begin{tabular}{cccc}
\hline Nature of Gender & Freq. & Percent & Cum. \\
\hline Female & 37 & 37.00 & 37.00 \\
Male & 63 & 63.00 & 100.00 \\
\hline Total & $\mathbf{1 0 0}$ & $\mathbf{1 0 0 . 0 0}$ & \\
\hline
\end{tabular}

Source: Field survey, 2015

Now let us see the scenario from the aspect of different size of farm. Table 83 below shows the gender distribution of small farm. Where we see that most of the small farms were operated by female farmers. Well this is not unexpected. Because in case of small farm female household plays pivotal role. Only in 33.33 percent cases small farms were being operated under male supervision. Practically women are more suitable than their counter part to operate small scale poultry farms more efficiently. Side by side of their household activities they can easily supervise the farming activities. Table 84 shows the gender distribution of medium farm. Where we see that in 32.35 percent cases farms were operated under female farmers while in 67.64 cases male farmers played main role in poultry farming activities. The size of farm is an important matter in deciding the role dominant by male or female farmers. From our study we see that only male farmers were operating poultry farming activities in large scale and no female farmers. 
TABLE 13

DISTRIBUTION OF RESPONDENTS ACCORDING TO GENDER (SMALL FARM)

\begin{tabular}{cccc}
\hline Nature of Gender & Freq. & Percent & Cum. \\
\hline Female & 26 & 66.66 & 66.66 \\
Male & 13 & 33.33 & 100.00 \\
\hline Total & $\mathbf{3 9}$ & $\mathbf{1 0 0 . 0 0}$ &
\end{tabular}

TABLE 14

DISTRIBUTION OF RESPONDENTS ACCORDING TO GENDER (MEDIUM FARM)

\begin{tabular}{cccc}
\hline Nature of Gender & Freq. & Percent & Cum. \\
\hline Female & 11 & 32.35 & 32.35 \\
Male & 23 & 67.64 & 100.00 \\
\hline Total & $\mathbf{3 4}$ & $\mathbf{1 0 0 . 0 0}$ & \\
\hline
\end{tabular}

Source: Field survey, 2015

TABLE 15

DISTRIBUTION OF RESPONDENTS ACCORDING TO GENDER (LARGE FARM)

\begin{tabular}{ccrr}
\hline Nature of Gender & Freq. & Percent & Cum. \\
\hline Female & 0 & 0.00 & 0.00 \\
Male & 27 & 100.00 & 100.00 \\
\hline Total & $\mathbf{2 7}$ & $\mathbf{1 0 0 . 0 0}$ & \\
\hline
\end{tabular}

Source: Field survey, 2015

\section{Marital Status of Layer Farm Owners}

Greater percentage of the respondents was married (87\%) while the rest of the farmers were single $(13 \%)$. This can be attributed to the fact that most married men are seen as being responsible and stand in advantage of obtaining loan/credit from financial institution, coupled with availability of more hands from their children who increase the labor needed in the enterprise, thereby aiding augmented productivity.

\section{TABLE 16 \\ DISTRIBUTION OF RESPONDENTS ACCORDING TO MARITAL STATUS (AGGREGATE)}

\begin{tabular}{cccr}
\hline Marital Status & Freq. & Percent & Cum. \\
\hline Married & 87 & 87.00 & 87.00 \\
Single & 13 & 13.00 & 100.00 \\
\hline Total & $\mathbf{1 0 0}$ & $\mathbf{1 0 0 . 0 0}$ & \\
\hline
\end{tabular}

Source: Field survey, 2015

\section{Training Facility of Layer Farm Owners in Sample Area}

From our study we see that most of the farmers which is 85 percent, received training. On the other contrary only 15 percent didn't receive training. Well this is good to think that most of the farmers in the study area were getting training facility. Only 15 percent farmers reported that they had not received prior training. 
TABLE 17

DISTRIBUTION OF RESPONDENTS ACCORDING TO ACCESS TO TRAINING FACILITY

\begin{tabular}{cccc}
\hline Access to Training Facility & Freq. & Percent & Cum. \\
\hline No & 15 & 15.00 & 15.00 \\
Yes & 85 & 85.00 & 100.00 \\
\hline Total & $\mathbf{1 0 0}$ & $\mathbf{1 0 0 . 0 0}$ & \\
\hline
\end{tabular}

Source: Field survey, 2015

Table 18 below shows the major sources of training of poultry farmers in sample area. The study revealed that in 55.29 percent cases farmers received training from experienced farmers. In most of the cases farmers know how passing time with some experienced one. And this is very helpful for them to get practical knowledge on poultry production system. Second major source of training was govt. youth institution (36.47 percent). Govt. provides free training facility or training at a very cheap cost. So this becomes easy for them to take knowledge on poultry. Only 8.24 percent farmers took training from NGO.

TABLE 18

DISTRIBUTION OF RESPONDENTS ACCORDING TO NATURE OF TRAINING

\begin{tabular}{crcc}
\hline Nature of Training & Freq. & Percent & Cum. \\
\hline Govt. Youth Institution & 31 & 36.47 & 36.47 \\
Experienced Farmer & 47 & 55.29 & 91.76 \\
NGO & 7 & 8.24 & 100.00 \\
\hline Total & $\mathbf{8 5}$ & $\mathbf{1 0 0 . 0 0}$ & \\
\hline
\end{tabular}

Source: Field survey, 2015

\section{Credit Facility of Layer Farm Owners in Sample Area}

Access to credit is an important instrument that enables farmers to acquire command over the use of working capital and proper inputs for a better yield. It is commonly believed that credit availability for small farmers is one of the main indicators of rural development. Table below shows that in 69 percent cases farmers had no access to credit facility in the study area. Only in 31 percent cases they had credit facility. The farmers who did receive credit were mostly large farmers. Small farmers in most of the cases did not receive credit facility which we see from our study.

TABLE 19

DISTRIBUTION OF RESPONDENTS ACCORDING TO ACCESS TO CREDIT (AGGREGATE)

\begin{tabular}{cccr}
\hline Access to Credit & Freq. & Percent & Cum. \\
\hline No & 69 & 69.00 & 69.00 \\
Yes & 31 & 31.00 & 100.00 \\
\hline Total & $\mathbf{1 0 0}$ & $\mathbf{1 0 0 . 0 0}$ & \\
\hline
\end{tabular}

Source: Field survey, 2015

In case of layer small farms most of the farmers (97.43 percent) did not receive access to credit facility while only 2.56 percent availed the credit facility. 
TABLE 20

DISTRIBUTION OF RESPONDENTS ACCORDING TO ACCESS TO CREDIT (SMALL FARM)

\begin{tabular}{cccc}
\hline Access to Credit & Freq. & Percent & Cum. \\
\hline No & 38 & 97.43 & 97.43 \\
Yes & 1 & 2.56 & 100.00 \\
\hline Total & $\mathbf{3 9}$ & $\mathbf{1 0 0 . 0 0}$ &
\end{tabular}

In case of medium farms most of the farmers (79.41 percent) also did not receive access to credit facility while only 20.58 percent get credit facility.

\section{TABLE 21
DISTRIBUTION OF RESPONDENTS ACCORDING TO ACCESS TO CREDIT (MEDIUM FARM)}

\begin{tabular}{cccc}
\hline Access to Credit & Freq. & Percent & Cum. \\
\hline No & 27 & 79.41 & 79.41 \\
Yes & 7 & 20.58 & 100.00 \\
\hline Total & $\mathbf{3 4}$ & $\mathbf{1 0 0 . 0 0}$ &
\end{tabular}

Source: Field survey, 2015

The case is largely different in case of large farms. In this case most of the farmers ( 85.18 percent) received access to credit facility while 14.81 percent did not get credit facility from bank or other financial institutions. Banks feel safe to provide loan to large farmers. In order to get the loan it requires different formalities which only large farmers can manage. That's why they get the loan facility.

TABLE 22

DISTRIBUTION OF RESPONDENTS ACCORDING TO ACCESS TO CREDIT (LARGE FARM)

\begin{tabular}{cccc}
\hline Access to Credit & Freq. & Percent & Cum. \\
\hline No & 4 & 14.81 & 14.81 \\
Yes & 23 & 85.18 & 100.00 \\
\hline Total & $\mathbf{2 7}$ & $\mathbf{1 0 0 . 0 0}$ & \\
\hline
\end{tabular}

Source: Field survey, 2015

\section{Visit of Extension Agent in Sample Layer Farm Areas}

It can be seen from the table below (table 23) that in 67 percent cases farmers were deprived of getting extension agent visit facilities while in 33 percent cases farmers got the facility. Those who got this most of them belong to large scale farmers as this can be seen from table 27 where almost all the large scale farmers ( 92.59 percent) reported that they were being visited by extension agent. Only two farmers reported that extension agent visit was not done. However, in case of small and medium scale farms the visit of extension agent was reported by 5.12 percent and 17.64 percent farmers respectively (table 25 and 26 respectively). In case of medium farms 82.35 percent farmers did not get the facility while 17.64 percent got the facility (table 25). The case is totally different in case of large farm. Here in 73.08 percent cases farmers get the facility while in 26.92 percent cases they did not receive the facility (table 26). Large farms are financially solvent enough to call for extension agent. Because of economies of scale they can afford this at cheap cost. For small farmers this is costly. 
TABLE 23

DISTRIBUTION OF RESPONDENTS ACCORDING TO VISIT OF EXTENSION AGENT (AGGREGATE)

\begin{tabular}{cccc}
\hline Visit of Extension Agent & Freq. & Percent & Cum. \\
\hline No & 67 & 67.00 & 67.00 \\
Yes & 33 & 33.00 & 100.00 \\
\hline Total & $\mathbf{1 0 0}$ & $\mathbf{1 0 0 . 0 0}$ & \\
\hline
\end{tabular}

Source: Field survey, 2015

TABLE 24

DISTRIBUTION OF RESPONDENTS ACCORDING TO VISIT OF EXTENSION AGENT (SMALL FARM)

\begin{tabular}{cccc}
\hline Visit of Extension Agent & Freq. & Percent & Cum. \\
\hline No & 37 & 94.87 & 94.87 \\
Yes & 2 & 5.12 & 100.00 \\
\hline Total & $\mathbf{3 9}$ & $\mathbf{1 0 0 . 0 0}$ & \\
\hline
\end{tabular}

Source: Field survey, 2015

TABLE 25

DISTRIBUTION OF RESPONDENTS ACCORDING TO VISIT OF EXTENSION AGENT (MEDIUM FARM)

\begin{tabular}{cccc}
\hline Visit of Extension Agent & Freq. & Percent & Cum. \\
\hline No & 28 & 82.35 & 82.35 \\
Yes & 6 & 17.64 & 100.00 \\
\hline Total & $\mathbf{3 4}$ & $\mathbf{1 0 0 . 0 0}$ & \\
\hline
\end{tabular}

Source: Field survey, 2015

TABLE 26

DISTRIBUTION OF RESPONDENTS ACCORDING TO VISIT OF EXTENSION AGENT (LARGE FARM)

\begin{tabular}{cccc}
\hline Visit of Extension Agent & Freq. & Percent & Cum. \\
\hline No & 2 & 7.40 & 7.40 \\
Yes & 25 & 92.59 & 100.00 \\
\hline Total & $\mathbf{2 7}$ & $\mathbf{1 0 0 . 0 0}$ & \\
\hline
\end{tabular}

Source: Field survey, 2015

\section{Occupational Status of the Layer Farm Owners}

The work or activity in which a farmer is engaged throughout the year is known as his main occupation of that person (Ray 1998). In the selected study area, the layer farm owners were engaged in different occupations along with layer farming. One of the most important reason of growing interest among people in poultry farming is that it requires less amount of time to invest. Poultry farming activities does not require investing full time effort in it rather it can be operated on part time basis. That's what we see from our study. The occupational status of the layer farm owners in the study area is given below in table 27. 


\section{TABLE 27 \\ DISTRIBUTION OF RESPONDENTS ACCORDING TO NATURE OF OCCUPATION (AGGREGATE)}

\begin{tabular}{cccc}
\hline Nature of Occupation & Freq. & Percent & Cum. \\
\hline Poultry as part time occupation & 89 & 89.00 & 89.00 \\
Poultry as part full time occupation & 11 & 11.00 & 100.00 \\
\hline Total & $\mathbf{1 0 0}$ & $\mathbf{1 0 0 . 0 0}$ & \\
\hline
\end{tabular}

Source: Field survey, 2015

From the table above we see that 89 percent poultry farmers were engaged in poultry activities as part time basis not in full time. Side by side of poultry farming they were engaged in some other agricultural and non-agricultural activities. This is an advantage of poultry business over other business that it does not require to invest full time effort. However, it can be seen from the table that only 11 percent farmers were doing poultry faring on full time basis. Of whom most of were large scale farm owners.

Table 28 shows that farmers who were operating small scale farms were doing poultry farming as part time basis in 100 percent. In case of medium farms we see that in 97.05 percent cases farmers were doing poultry business as part time while in 2.94 cases farmers were doing poultry business as full time basis (table 99). However the scenario was different to some extent in case of large farms.

TABLE 28

DISTRIBUTION OF RESPONDENTS ACCORDING TO NATURE OF OCCUPATION (SMALL FARM)

\begin{tabular}{cccc}
\hline Nature of Occupation & Freq. & Percent & Cum. \\
\hline Poultry as part time occupation & 39 & 100.00 & 100.00 \\
Poultry as full time occupation & 0 & 0.0 & 0.00 \\
\hline Total & 39 & 100.00 & \\
\hline
\end{tabular}

Source: Field survey, 2015

TABLE 29

DISTRIBUTION OF RESPONDENTS ACCORDING TO NATURE OF OCCUPATION (MEDIUM FARM)

\begin{tabular}{cccc}
\hline Nature of Occupation & Freq. & Percent & Cum. \\
\hline Poultry as part time occupation & 33 & 97.05 & 97.05 \\
Poultry as full time occupation & 1 & 2.94 & 100.00 \\
\hline Total & $\mathbf{3 4}$ & $\mathbf{1 0 0 . 0 0}$ & \\
\hline
\end{tabular}

Source: Field survey, 2015

In case of large scale farm we see that many large scale farmers were engaged in poultry business as full time basis. Farmers engaged in poultry business as full time basis was 37.03 percent while it was 2.94 percent in case of medium farms. This is because poultry farming in large scale requires much effort than to small or medium scale. Particularly in case of layer farming in large scale operating other agricultural or non-agricultural activities side by side doing poultry farming is much more difficult. That's why we see that large scale farmers keep their full concentration in poultry business and no other job(s). Large scale farming activities demands much attention, much effort to be developed. 
TABLE 30

DISTRIBUTION OF RESPONDENTS ACCORDING TO NATURE OF OCCUPATION (LARGE FARM)

\begin{tabular}{cccc}
\hline Nature of Occupation & Freq. & Percent & Cum. \\
\hline Poultry as part time occupation & 17 & 62.96 & 62.96 \\
Poultry as full time occupation & 10 & 37.03 & 100.00 \\
\hline Total & $\mathbf{2 7}$ & $\mathbf{1 0 0 . 0 0}$ & \\
\hline
\end{tabular}

Source: Field survey, 2015

\section{Other Sources of Income of Layer Farm Owners in Sample Area}

In the study area the other income sources of the farmers were agriculture, service, business, fisheries and livestock. Greater percentage (28.09 percent) had crop cultivation as a major occupation. Second source of income poultry farm owners generate (which was 24.36 percent) was other livestock raising. small business activities such that tea stall, selling livestock vaccine, medicine, selling daily green vegetables and curries, easy bike and CNG scoter driving, mobile operation etc. ranked three which was 24.72. Fish cultivation was ranked after small business which was 16.85 . Service holder ranked least i.e. 3.37. By service holder we mean people who were employee of any govt. or non govt. institution.

\section{TABLE 31 \\ OTHER SOURCES OF INCOME OF SAMPLE LAYER FARM OWNERS}

\begin{tabular}{cccc}
\hline Other Occupation & Freq. & Percent & Cum. \\
\hline Other livestock raising & 24 & 26.97 & 26.97 \\
Crop cultivation & 25 & 28.09 & 55.06 \\
Fish cultivation & 15 & 16.85 & 71.91 \\
Service holder & 3 & 3.37 & 75.28 \\
Small business & 22 & 24.72 & 100.00 \\
\hline Total & 89 & 100.00 & \\
\hline
\end{tabular}

Source: Field survey, 2015

In the study area the other income sources of the farmers were agriculture, service, business, fisheries and livestock. Greater percentage (28.09 percent) had crop cultivation as a major occupation. Second source of income of poultry farm owners was other livestock raising which was 26.97 percent. Small business activities such that tea stall, selling livestock vaccine, medicine, selling daily green vegetables and curries, easy bike and CNG scoter driving, mobile operation etc. were ranked third (24.72). Fish cultivation activities ranked four which was 16.85 percent. Service holder ranked least i.e. 3.37. By service holder we mean people who were employee of any govt. or non govt. institution.

Respondents rated lack of sufficient capital as an important problem. This could be the reason why farmers could not acquire the necessary inputs particularly fixed inputs for large scale production which attracts higher profit and efficiency. 


\section{Social and Natural Constraints}

Social and natural problems are problems that cannot be solved easily. Among various problems, 41 percent of farm owners agreed that farming creates pollution (Table 32). On the other hand, in the study area, 32 percent farmers complained about predatory problems. 27 percent of layer farm owners indicate theft problem.

In case of layer farm, 41 percent farmers complained about environment pollution while 31 percent mentioned about problem of stealing and 28 percent complained about predatory animals as constraints. 


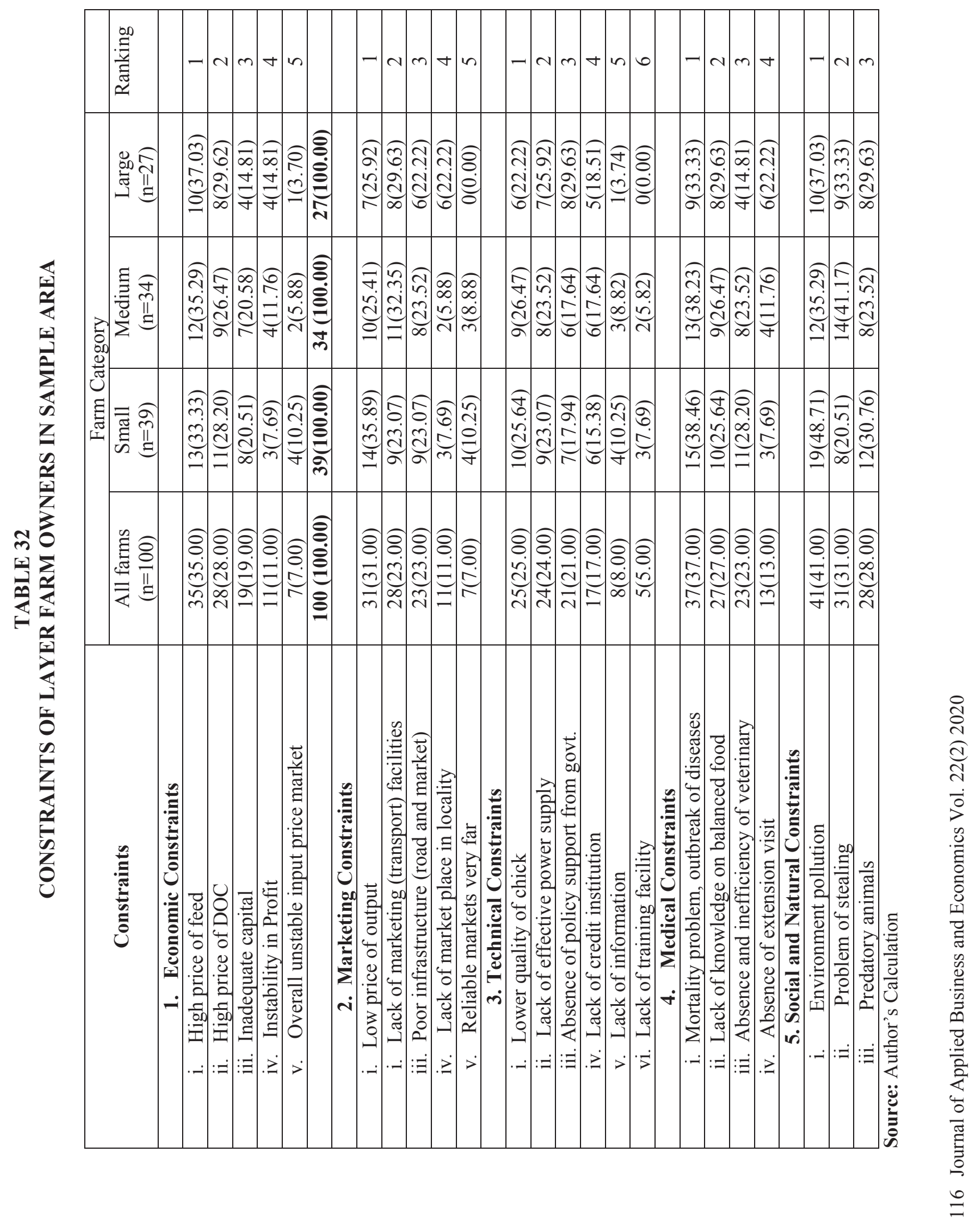




\section{CONCLUSIONS}

In this study factors affecting layer output has been estimated by using Cobb Douglas production approach. The results of the study give information to policy makers on how to better aim efforts to improve poultry production. Doc size and feed input play most crucial role in layer output. So price stability of these two inputs should be given highest priority. And remedial measures should be taken against different constraints faced by the farmers.

The long-term position of Bangladesh as a prominent producer of poultry products leftovers bright even after the bird flu epidemic that has held off its prospect. The swelling demand for poultry meat and eggs has improved poultry activity into a full-grown industry from a mere household activity until recently. The poultry industry has immense potential for boosting the economic growth of the country as well as ensuring food security. Agricultural land is limited and is reducing day by day. A solution to the issue of farmland depletion could be formulation of a sensible and realistic land-use policy. Poultry is most probably the only sector that can grow vertically and produce maximum amount of eggs and chicken meat using the minimum land. All categories of stakeholders should partake in policy formulation for the development of the poultry industry. The sector will contribute more than it is expected to be if proper policy is taken and will contribute to the country's GDP leading a strong domestic economy of the country.

\section{ENDNOTE}

1. Associate Professor, Department of Economics, Bangladesh University of Business and Technology (BUBT), 77-78, Campus-2, 77-78, Rupnagar Residential Area, Road No. 9, Dhaka 1216, Bangladesh. The article is part of my Ph.D. thesis work done in Jahangirnagar University, Savar, Dhaka, Bangladesh.

\section{REFERENCES}

Abedullah, Kouser, S., and Mushtaq, K. (2007). Analysis of technical efficiency of Rice production in Punjab (Pakistan): Implications for future investment strategies. Pakistan Economic and Social Review. 45(2), 231-244.

Ahmed, S. U., Ali, M. S., \& Begum, A. (1995). "An Economic Study on the Performance of Broilers and Layers Round the year", Bangladesh Agricultural University Research Progress

Ahmed, M. F. U. (2001). "A comparative Economic analysis of broiler production under PROSHIKA supervision and private management in some selected areaTangial district". M.S. Ag.

Econ.Thesis, Dept. Of Agricultural Economics, Bangladesh Agricultural University, Mymensingh

Akter $\mathrm{N}$ et. Al., (2004) "Challenging the frontiers of poverty reduction/target ting the ultra-poverty program", BRAC

Ajibefun, I. A., Battese, G.E., \& Kada, R. (2002). "Technical Efficiency Technological Change and Productivity of Hired and Family Labor in the Japanese Rice Industry". Empirical Economic Letters, (1), 21-31

Alam M. (2017), "Feasibility Study of Biogas Energy in Bangladesh" Retrieved from http://dspace.daffodilvarsity.edu.bd:8080/bitstream/handle/20.500.11948/1597/P05049.pdf?seque nce $=1 \&$ isAllowed $=y$

Alam, S. M. (2004). A study in Backward and Forward Linkage of Poultry Farming in Some selected Areas of savarupazila under Dhaka district. Unpublished M. S. Thesis, Department of Agricultural Economics, Bangladesh Agricultural University, Mymensingh

Alrwis, K. and E. Francis, (2003). Technical, Allocativeand Economic Efficiencies of Broiler Farms in theCentral Region of Saudi Arabia: Data EnvelopmentAnalysis Approach. Journal of Saudi Society ofAgricultural. Science, 1(2), 73-99 
Bairagi, S.K. (2004), “An Economic Study of Contract Broiler Farming with Reference to Supply Chain Management. M.S. Ag. Econ. Thesis, Dept. of Agricultural Economics, Bangladesh

Agricultural University, Mymensingh"

Bangladesh Economic Review. (2017), Chapter 7, Agriculture, page 111

Banglapedia, National Encyclopedia of Bangladesh

Bhuiyan, H. A. (2003). A Comparative Economic Analysis of Poultry Production under Supervision of AftabBahumukhi Farm and Farmers own Management in Some Selected Areas of Kishoreganj District. Unpublished M. S. Thesis, Department of Agricultural Economics, Bangladesh Agricultural University, Mymensingh

Ellis F. (1988) Peasant Economics: Farm households and Agrarian Development. Cambridge University Press, Cambridge. 257-259.

Ershad, S. M. E., Islam, S. S., Mandal, S. C., \& Sarker, B. (2004). 'Efficiency of Farmer's on the Productivity of Broilers in a Selected Area of Bangladesh'. International Journal of Poultry Science', 3(8), 503-506

FAO. (2009). Consumer preferences for poultry products in Indonesia.Prepared by MuladnoMuladno and O.Thieme.GCP/RAS/228/GER Working Paper No. 12. Rome

FAO 2015.The State of Food Insecurity in the World. (2015). Meeting the 2015 International Hunger Targets: Taking Stock of Uneven Progress. FAO, Rome 2015

Haider M. Z., Ahmed M. S. \& Mallick A., (2011, August), "Technical Efficiency of Agricultural Farms in Khulna, Bangladesh: Stochastic Frontier Approach", International Journal of Economics and Finance, 3(3).

Hasnain, M. N., Hossain, M. E., \& Islam, M. K. (2015). Technical efficiency of boro rice production in Meherpur district of Bangladesh: a stochastic frontier approach. American journal of agriculture and forestry, 3(2), 31-37.

Hassan, Md. M., (2018, March), “Application of Stochastic Frontier Model for Poultry Broiler Production: Evidence from Dhaka and Kishoreganj Districts, Bangladesh", Bangladesh Development Studies, XLI(1).

Hassan, Md. M. (2019, March), "Entrepreneurial Prospects of Poultry Layer Farming in Bangladesh: A Stochastic Frontier Analysis" The IUP Journal of Entrepreneurship Development, Hyderabad, IUP Publ., India, XVI(1)

Isika, M. A., Agiang E. A., \& Okon, B. I. (2006). Palm oil and animal fats for increasing dietary energy in rearing pullets.IntPoulSci, 5, 43.

Islam K., \& Nabiul, M. (2001), "Demand for Poultry Feeds: Implications For Wheat and Maize Production in Bangladesh"

Islam et al. (2016) J. Biosci. Agric. Res. 08(01), 678-684.

Jabbar Mohammad A., et. al. (2007) "Formal and informal contract farming in poultry in Bangladesh", World Poultry Journal.

Karim, M. A. (2000), "An Economic Analysis of broiler enterprise under contract farming system in an areas of Bangladesh, M.S. Ag. Econ. Thesis, Dept. of Agricultural Economics.

Kamruzzaman, M. M., Manos, B., \& Begum, M. A. A. (2007). "Evaluation of Economic Efficiency of Wheat Farms in a Region of Bangladesh Under the Input Orientation Model". Journal of the Asia Pacific Economy, 11(1), 123-142,

Kibaara, B.W. (2005). Technical efficiency in Kenyan's maize production: an application of the stochastic frontier approach. In partial fulfillment of the requirements For the Degree of Master of Science Colorado State University Fort Collins, Colorado

Khan, Zahan, Anower, (2016), "POULTRY FARM BASED BIOGAS POLICY IN BANGLADESH", Journal of Electrical Engineering

Khan M. M. et. al. (2006), “The Status of Homestead Poultry Production in Sylhet Region”, International Journal of Poultry Science, 5(11), 1092-1095.

Layer rearing manual. (2010), Bangladesh Livestock Research Institute, BLRI, pg. 8. 
Miah, M. T. H. (1990), "Economics of commercial poultry farming in Bangladesh, Report No. 21, Bureau of Socioeconomic Research and Training, Bangladesh Agricultural University, Mymensingh

Ohajianya, D.O., Obasi, P.C., \& Orebiyi, J.S. (2006) "Technical Inefficiency and its Determinants in food crops production in Imo State, Nigeria".Journal of Agriculture and Social Research, 6(1), 9-16.

Park, S. E., Howden, S. M.., Crimp, S. J., Gaydon, D. S. Attwood, S. J., \& Kokie, P. N. (2010). More than Eco-efficiency is required to improve food security. Crop Sc., 50, 132-141

PerminA., Pedersen G., \& Riise J.C. (2003), "Poultry as a Tool for Poverty Alleviation: Opportunities and Problems Related to Poultry Production at Village Level", Network for Smallholder Poultry Development, The Royal Veterinary and Agricultural University, Bülowsvej

Parikh, A., \& Shah, M. (1995). Measurement of Technical Efficiency in the North - West Frontier Province of Pakistan. Journal of Agricultural Economics, 45(1), 132-138.

Pasour, E. C., Jr. (1981). A further Note on the Measurement of Efficiency and Economics of farm size. Journal of Agricultural Economics, 32(2), 135-149.

Rahman, T. K. (2004). Marketing System and Consumer Performance for Broiler with Emphasis on Impact of Bird Flue Rumor in an Area of Bangladesh. Unpublished M. S. Thesis, Department of Agricultural Marketing, Bangladesh Agricultural University, Mymensingh

Rahman, B. et. al., (2009), "A study on profitability of contact broiler farming system at Bajitpur", Bangladesh Journal of Livestock Research, 16(1\&2), 105-108.

Sarker, S. C., Abedin, J., \& Islam, S. M. F. (1999). 'Performance of Commercial Poultry Farms.A Profitability and Efficiency Analysis'. Bangladesh Journal of Agricultural Economics, 22(1)6364

Sajib, Hassan, M., \& Hoque, S. M. (2015), "Electricity Generation from Poultry Waste in Bangladesh", Retrieved from http://icmimeruet.ac.bd/2015/DIR/Contents/Technical\%20Papers/Energy\%20Technology/ET18.pdf

Shamsuddoha, M. (2009), "Development of Livestock Sector Through Leading NGO in Bangladesh", The Annals of the Stefan cel Mare, University Suceava, Fascicle of the Faculty of Economics and Public Administration.

Shamsuddoha, M. (2010). "A sustainable supply chain process model for Bangladeshi poultry industry", Doctoral Students Colloquium 2010 (Vol. 1). Perth, Australia: Curtin Business School.

Shah, S., Sharmin, M., \& Haider, S. (2011), "Problems of small to medium size poultry farmsBangladesh perspective", Department of Pharmaceutical Technology, Faculty of Pharmacy, University of Dhaka, Bangladesh.

Uddin, Hossain, Hasnain, (2017), "Efficecny of Maize Production in Bangladesh: A Stochastic Frontier Approach", Retrieved from http://www.sb.iub.edu.bd/wp-content/uploads/2017/12/7V.pdf

Ukil, M. A., \& Paul, D. C. (1994). 'Problems and prospect of poultry industry in Chittagong region', Papers presented to the Bangladesh Animal Husbandry Society Conference, Dhaka, December 1994.

USAID-ATDP. (2005). “Issues and Interventions in Poultry Sector Final Report”, USAID - ATDP II Undertaking

Yao, S., \& Liu, Z. (1998). "Determinants of Grain Production and Technical Efficiency in China"; Journal of Agricultural Economics, 49(2), 171-184.

Zaman S. A. U. (2007). "The Potential of electricity generation from poultry waste in Bangladesh: Case study of Gazipur District" 